\title{
THE REDISCOVERY OF JESUS AS A LITERARY FIGURE
}

Georg Langenhorst

SURPRISINGLY ENOUGH in the present discussion about "Literature and Theology" within the English-speaking world, the most important general studies ${ }^{1}$ hardly ever mention the central figure of Christianity, Jesus Christ himself. Much can be read about hermeneutics, deconstruction and aesthetics, but very little about Christ. This is even more surprising when we come to realize the fact that there has been an astonishing rediscovery of Jesus as a literary figure over the last 20 years. One may even speak of a literary renaissance of Jesus, especially of the "Jesus-novel". Thus the present artacle first of all tries to present the nch literary tradition dealing with Jesus in some kind of an annotated bibliographical survey. At the same time it wants to bring the literary methods used to a critical discussion and consider the theological impact of this new tradition of Jesus-novels.

Jesus as a literary character

More than twenty years ago, the American critic Theodore Ziolkowski published his foundational study Fictional Transfigurations of Jesus, ${ }^{2}$ sall well worth reading. Here he presents a vivid picture of the traces of Jesus in world-hterature. He concentrates however on "transfigurations" only, that is on narratives, " $1 n$ which the characters and the action ... are pre-figured to a noticeable extent by figures and events popularly associated with the life of Jesus as it is known from the Gospels". "Thus he thereby excludes among other things, what he calls, "fictionalizing biographies" Nikos Kazantzakis' The Last Temptation of Christ (1953), Pär Lagerkvist's Barabbas (1950) or Lloyd C. Douglas' The Big Fisherman (1948), dismissing them all too easily as works of no "literary distinction". ${ }^{5}$ But there can be little doubt that these novels are still important literary witnesses of their time: they were widely read and thus, very influential in forming the image of Jesus particularly in pre-Vatican II catholic societies, where Bible-reading was little practised. Moreover, they undoubtedly corresponded to the literary fashion of their days-Lagerkvist was awarded the Nobel prize for his novel!

However, a critical evaluation of these books today requires a more differentiated judgement. Ziolkowski is right in saying that these novels do not fulfil the literary and, one may add, the theological requirements of the 
sixties and seventies. Quite obviously, the fifties mark not only the peak of this genre but also, its end. The hterary and theological context of the following years demanded something new. Why? Two very concise remarks have to be enough here. First to the literary context: in the increasingly pluralistic world of the sixtes monoperspectavical novels with omiscient narrator-figures and clearly and well defined messages simply grew out of fashion. They could no longer represent the spirit of the times. And as to the theological context: in a time where the insights of modern biblical scholars became more and more accepted by church-leaders and a growing number of church-members, a mere outline or colourful reproduction of the biblical narratives, without any critıcal questions about the historicity of the events could no longer be seen as a real challenge. Was this then the end of the Jesus-novel?

Alongside the tradition just described, Zıolkowskı ıdentifies another literary tradition, which does not try to portrait Jesus in his tume, but to write about Jesus-figures in our time. ${ }^{6}$ He finds such "transfigurations" of Jesus in novels by authors like Gerhart Hauptmann, John Steinbeck, Willam Faulkner, or John Barth. He argues first that this literary tradition of adopting Jesus is the only interesting one, the only one well worth regarding in the future, and secondly, that the more distance these novels have to the original in matters of style, form and "message" the better they are as works of literature.

Sxx years after the publication of Ziolkowski's book, the German theologian and literary critic Karl-Josef Kuschel publıshed his study Jesus in Contemporary German Literature. ${ }^{7}$ Kuschel agrees with Ziolkowski on his first claim: direct presentations of Jesus in literary works of art seem to belong to the past. However, he sharply disagrees with Ziolkowski on the second point for two reasons: first of all, by arbitrarily dismissing the theological dimension Ziolkowsk1 - as a literary critic - cannot appreciate why so many contemporary authors in fact turn their attenton to Jesus: secondly, by ignonng the biographical, philosophical and theological reasons for the literary adaption of Jesus, Zlokowski's interpretations very often fall to grasp the function of the respective presentation of Jesus. Thus, in its final judgements, hus study remauns superficial.

The same must be conceded to a recent book by Willam Hamilton, $A$ Quest for the Post-Historical Jesus (1993), where he concentrates on the reception of Jesus outside the theological realm. Without regarding etther Ziolkowskn or Kuschel, Hamilton's thoughts about the reception of Jesus in contemporary films, novels, poetry, plays and philosophical essays, remain very much on the level of personal remarks without any systematic concept. Together, these three critics believe and show, that Jesus is present in contemporary literature primarily in an indirect, "transfigural", hidden way. With the help of many examples (Max Frisch, Heinrich Böll, Rolf Hochhuth, Nelly Sachs, ...) 
Kuschel even demonstrates that in fact Jesus is "the most importantsometimes direct, sometimes hidden - figure of reference" in contemporary novels, drama and poetry.

Moreover, many examples of extended fictional transfigurations of Jesus can be found in contemporary literature. Two such examples here: In Il quinto Evangelio ${ }^{9}$ (1975) the Italian novelist Mano Pomilio gives a thrilling account of the search for a "fifth gospel" in our time. The novel uses many different literary forms and ends with a little drama that transforms the biblical events to a scene in Nazi-Germany in 1940 where the actors identify themselves more and more with the roles they play. Pomwo thereby takes up a tradition developed by the Greek novelist Nikos Kazantzakıs in his Jesustransfiguration-novel from 1954 Christ Recrucified. Again in John Irving's A Prayer for Owen Meany (1989) the protagonist is directly called a "second Christ". Throughout this novel, often rather obscure parallels between the weird American youth and later soldier Owen Meany and Jesus Christ, are drawn out.

Over the last twenty years, however, a very remarkable development can be observed. Whereas the direct literary presentation of Jesus in hus tume, the so called "fictionalizing biographies", seemed to have died out in the late fifties, the genre has experienced something that may well be called a renaissance, a widespread rediscovery of Jesus as a literary figure, of Jesus in his time. ${ }^{10}$ Can these recent novels be considered direct inheritors of the works of the fiftues mentioned above? Should they likewise be dismussed as works of "no literary distunction" - to take up Ziolkowski's verdict? Or do they use new literary techniques to present Jesus in a contemporary novel? Can they be seen as a challenge to theological interpretations of Jesus?

\section{Live from Golgotha? Eyewitnesses report}

In I992 Gore Vidal, one of America's most prolific and respected writers, published his twenty-third novel under the title Live from Golgotha. ${ }^{11}$ In this satirical comedy Vidal, who had already published a novel in the tradition of the "fictional transfigurations of Chnst" with his Messiah in 1954, presents what may be best described as the first postmodern and futurntic novel on Jesus. The novel is set in a future in which $\mathrm{H}$. G. Wells' vision of the tume machine has become reality: a computer programme has been developed that allows not only journeys back into the past but also the possibility of changing the historical events themselves. In this situation a computer-hacker succeeds in destroying all the tapes recording the life and message of Jesus-all the tapes except one, a "Gospel according to Timothy", St Paul's disciple. This "Gospel" alone secures that future generations will know about the life and teachings of Jesus, Paul and the other apostles.

The main action of the novel takes place in the year $95 \mathrm{AD}$. Timothy, in 
his old age a bishop in Macedonia, is about to write down his memories about Jesus, Paul and the beginnings of Christranity, when he is suddenly confronted by visitors from the future-Mary Baker Eddy, Shirley MacLaine and others - seeking to influence the histoncal events or at least their recording in the "Gospel according to Timothy". Being told that his "Gospel" will be of the utmost importance for the very existence and the future of Christianity, Timothy becomes more and more confused about what really happened: was it Judas who was crucified instead of Jesus? Was it Paul who invented the "Good News" very much against the teachings of Jesus? Who are the different characters trying to influence Timothy and for what purpose? Finally a television crew manages to enter the stage in the year 33 , ready to record the resurrection "live from Golgotha" for the eyewitness of the world in the last years of the twentieth century. Their version of the story however proves to be a manipulation of history by a group of Japanese film-tycoons: "Jesus returns to his ancestress, the Goddess of the Sun" (p. 224) and the "new logo of Christianity" becomes "the cross withun the circle of the sun" ( $\mathrm{p} 225$ ).

Vidal's very funny, highly imaginative novel is full of allusions to other works of "religious literature" (Dorothy Sayers, Mary Gordon, Franz Werfel), Jesus-movies, contemporary figures and events, and as such is a satirical persiflage on the computer-, television- and film-scene. Beneath the genual flippancy of Timothy's reports, however, he some very interestung and well written passages about Paul's journeys and missionary activities, his controversies with Peter and James in Jerusalem, or the slow, sometimes spontaneous development of this theological system. Timothy-and presumably Vidalconcludes: "The Jesus story was never much of anything untl Saint (Paul) cooked up the vision-on-the-road-to-Damascus number and then pulled the whole story together" (p. 173).

A closer look at the tradition of the Jesus-novels reveals however, that Vidal was not the first author to introduce the medium of television or film into such a novel. The fundamental idea of confronting the histoncal proceedings around Jesus with the modern techniques of television recordings had already been employed in 1966, when the British author Stuart Jackman published his book The Davidson Affair, where a Roman television team tnes to document and discuss the rumours of Christ's resurrection from the dead in Jerusalem. Like Vidal, Jackman tries to present the Jesus-story by using modern everyday language, but unlike Vidal he does not use irony and sature as hus main literary means. In intervews with Pilate, Caiaphas, Mary Magdalene and many other biblical characters, the historical evidence of what had happened and the different interpretations of events are brought to light. Unfortunately, Jackson tries to combine this interesting technique with the traditional device of a conversion-story: the journalist who is responsible for 
the programme is finally converted to believe himself in the basic assumptions of Christianity. Problematic in Jackman's novel is its dependence on outdated theology and a traditionalist exegesis. Like his second novel on the same subject from 1982, The Davidson File, where he presents the whole story in the form of a secret-service file, this novel fails to serve as a serious theological challenge, because its christological implications primarily appeal to fundamentalusts.

The same can be sard about another novel that employs the technique of a time-machine in order to present a contemporary of our time as an eyewitness of the crucial events in Jerusalem 2000 years ago. In I984 the Spanish author J. J. Benitez published his highly successful science-fictionnovel Caballo de Troya (the title of the German version is Operation Jesus), where an Amencan scientist is sent back to meet Jesus, talk to him and give witness to all the events recorded in the gospels. Benitez and Jackman try to bring the literary form of the classical Jesus-novel in line with the literary demands of our tames, but they fail to do the same with the theological demands.

Pilate, Judas and Mary Magdalene-Jesus seen through the eyes of biblical characters Although the postmodern and futuristic approach of Vidal was already prefigured by Jackman and Benitez, in its highly imaginative form and its well calculated theological provocations hus book was something new in the tradition of the Jesus-novel. Vidal had not been the first contemporary author who tried to present his own literary view of the Jesus-story through the eyes of a biblical figure. There is, for example, a whole literary tradition that centres on the character of Judas, the most mysterious figure in the New Testament. Was he really the trattor of Jesus, damned for his deed for all eternity? But then why did Jesus - the saviour of mankind-allow hum to do what he did? How could he let him stumble into his destny? No, the story must have been different from the versions we have in the gospels. Thus at least is the conclusion of four different modern authors: the German wnter and literary critic Walter Jens in his highly sophisticated novel Der Fall Judas, published in 1975 , the American playwright Peter Ury in his "miracle play" The Kiss of Judas which appeared one year later, Taylor Caldwell ${ }^{12}$ in her late novel I, Judas from 1977, and the Italian novelist Giueseppe Berto, who published his novel La Gloria, a seemingly autobiographical attempt of Judas to justify his life, in 1978 . They all present a new view of Judas, trying to rehabilitate him and even promote him as a sant. Judas, as they see him, was not the traitor of Jesus, but his closest friend, necessary in the plan for the world's salvation, who voluntarily accepted the part designed for him.

Next to Judas it was especially the historical figure of Pontius Pilate, that has always fascinated and disturbed readers of the New Testament. Was he 
personally responsible for the death of Jesus? How did he go on living after sentencing Jesus to death? "Jesus the Nazerene? I don't remember him"these were the last words of Plate according to the short story "Le procurateur de Judeé" (1892) of the French Nobel prize winner Anatole France. Many other authors have reflected on Pontuus Pllate and his relationship to Jesus: one of the earhest stories of the Swiss writer Friednch Duirrenmatt deals with Pontius Pilatus (1949), the Catholic novelist Gertrud von le Fort wrote a novella Die Frau des Pilatus (1955) and the French writer Roger Callois a report on Ponce Pilate (196I), the American author Paul L. Maier published a mixture of hustorical study and novel in hus Pontius Pilate in 1968, and the Russian novel The Master and Margarita by Michal Bulgakov, written in the thirties but published much later, centres on fictional dialogues between Pulate and Jesus.

The most important contemporary novel that confronts Jesus with Pilate is very much indebted to Bulgakov. Once again it is a novel written in Russia, published under the tutle Placha. The Place of the Skull in 1986. The author, Tschingis Aitmatow, was born as a Moslem in Kirgisia. There have been novels about Jesus written by non-Christan authors before: we need only to mention Schalom Asch's The Nazarene (1939) or Max Brod's Der Meister (1952). They, however, were written by Jews who had an interest in the Jewish man Jesus of Nazareth. Placha is the first Jesus-novel of importance written by an author with neither Jewish nor Christran background, by a writer from a Moslem background who declares himself to be an atheist. Why does such an author write a novel about Jesus?

Placha is a very complex novel with many different strings of action. At the centre of it we are confronted with a dialogue of some thirty pages between Jesus and Pilate in form of a vision of the protagonist Awdij. Awdij, a former candidate for the presthood who had to leave the seminary because of his unorthodox ideas now wants to write an article about the cultivation of drugs in Kurgesia. When his intention is discovered he is badly beaten up and, fightang with death, he expenences a vision of Jesus. In a visionary dialogue Pilate becomes the frustrated materialst who believes that mankınd finally faces its end and that the man-made apocalypse is near. Against this radical scepticism Jesus presents a message of hope. He beleves in a "heavenly gift" to mankınd and that is "reason". Jesus himself has come to earth as an "eternal example" to demonstrate how man shall live in order to survive.

This message of a last hope in the face of the apocalypse is however threatened in the book itself by the fate of Awdij. He survives only to be hung on a tree with his arms stretched out. The tendency to identify Awdij with Jesus is drawn out even more directly, in as much as his torturers call him ironically the "New Christ". Thus in Placha Artmatow combines two literary traditions: by means of a vision he presents Jesus in his own tumes, 
and at the same tume he presents the subject of this vision, Awdij, as a new transfiguration of Christ. On the level of the text this novel seems to end in pessimistac resignation. There seems to be no realistic reason for the message of hope preached by Jesus. The book as such however was written as a warning to mankund to make good use of reason and to create a better world worth living in. It is surprising, of course, that the atheistic Moslem Aitmatow chose Jesus as a figure to deliver such a message. But as Aitmatow sard in an interview, it was at this very moment that his "turn to the message of Christianity" became inevitable: more than any other figure of mankind, more than Mohammed, Moses or Buddha, Jesus as a martyr becomes a symbol of hope. "I turn to Chnst in order to say somethung absolutely essental to the humankund of our times. That is the reason why this figure appears in my novel". ${ }^{13}$

Besides Judas and Pontius Plate there have been many other biblical characters through whose eyes writers of our times have tried to portray Jesus. In I983 one of the most important female writers of contemporary Germany, the Bavarian author Luse Rinser presented her vew of Jesus in her widely read novel Mirjam. Through the eyes of Mary Magdalene, Rinser gives her own account of the Jesus-story. By giving the characters their original Jewish names-Mary Magdalene is Mirjam, Judas is Jehuda, John is Jochanaan, Jesus is Jeshua - Rinser's novel tries to establish a reliable historical authenticity. Following the biblical accounts very closely Rinser makes Jesus pronounce her favounte personal ideas without any inhibitions. Thus she gives testimony of her own threefold behef: first in the message and person of Jesus, but not in the church in its contemporary structure and form; second in the necessity and possibility of a feminis reconstruction of Chnstianity; and third in the radical pacifism that stood nght in the centre of the message of Jesus.

If her thoughtfully constructed and well written novel does not totally succeed it is for two main reasons. The first is a literary one: her monoperspectivical presentation of Jesus fals to fulfil the requirements of a contemporary novel in terms of the necessary differentration and complexity. Runser serves . as a typical example of an author who adopts the tradition of the classical Jesus-novel without transforming it and without adapting it to the present literary situation. The second is a theological reason. Rinser tries to follow two different lines which obviously are incompatible on a literary level: she wants to present the concrete Jewish man Jeshua and at the same time the Christ as the son of God. Many christological statements that reflect the later theology of the belief in a resurrected Christ simply do not fit into the mouth of the living Jew Jeshua. All too easily she neglects the necessary theological differentiation between the histoncal Jesus and the later Chnstian reflections about his nature, and the result is an unsatisfactory mixture of a Jesus, half 
human and half divine. This concept, however, does not seem to work in a modern piece of literature.

The aspect of a feministic re-reading of the Bible story is stressed much more and developed on a much more radical level in another contemporary novel on Mary Magdalene by the Anglo-French author Michèle Roberts, who published her novel The Wild Girl in 1984. Through the eyes of her heroine, Roberts tries to present a new form of Christranity that embraces the female equally with the male and acknowledges women's spirituality. ${ }^{14}$

Other attempts to give a literary portrait of Jesus from the perspective of biblical characters include another novel by the Jewssh author Schalom Asch, Mary (1949), where the events are retold by the mother of Jesus. A similar report by Joseph, her husband, can be found in the Polish novel Cien Ojca (1977) by the Catholic author Jan Dobraczynski, who in 1952 had already published his immensely successful novel Listy Nikodema, where the Jesusstory is retold by Nicodemus in a senes of letters. In I985 the French novelist Guy Hocquenghem gave his literary version of the life and theology of John the apostle in his book La colère de l'Agneau (The Wrath of the Lamb). The latest example of this tradition dates from 1993, when the Amencan author Wilton Barnhardt published hus second novel Gospel, where he presents an adventurous search for a long forgotten authentic gospel, written by the thirteenth apostle Matthias.

Already in 1978 another French writer called Jean-Claude Barreau had published Les Mémoirés de Jésus, a seemungly autobiographical report of Jesus himself. The Irish author Peter de Rosa published his literary report on the life of Jesus from his birth up to the tume when he started his public career under the tutle The Hidden Years in 1984. And one of Portugal's most important contemporary authors, José Saramago, took up these ideas when he wrote O Evagelho segundo Jesus Cristo (The Gospel According to Jesus Christ) in I99I. In conclusion the Italian novelist Franco Ferruci chose in his sophisticated satincal novel $I l$ mondo creato (The Creation) (I986) the perspectuve of God the Father himself, who reflects about his creation and then in a small chapter in the middle and centre of thus book meets hus son Jesus: a long list of utles with many different perspectuves and many different intentions. But they all present a monoperspectuval view of Jesus and his times.

Jesus and his contemporaries

As the brief survey above has shown there is a broad tradition of novels about Jesus which try to retell the events through the eyes of one single biblical character. In his novel The Davidson Affair Jackman was one of the first authors who tried to present not just one, but many different contemporarres of Jesus giving their own accounts of what had happened. This literary technque can be found in a couple of other, much more convincing novels. 
In 1983 the Austnan author Gertrud Fussenegger published a novel called Sie waren Zeitgenossen (They uere Contemporaries). This book employs the form of a collage in order to present many different reports about Jesus-once again he is called by his Jewish name Jeshua-and his time. The collage consists of letters, short reports, notes, quotations from the works of the historian Flavius Josephus, the Bible, and so on. The main advantage of this technique lies in its polyperspectivity. Instead of one subjectnve voice we hear many different accounts of what has happened and thereby get a much more differentrated picture. Instead of hearing the confession of one individual 'from the inside', we are confronted with many different preces of unformation 'from the outside'. Thus Fussenegger does not have to give us a physical descnption of the outlook of Jesus - always a difficult affair in a novel, and hardly ever convincing - and does not have to pretend to reproduce directly the words of Jesus, but rather shows what his contemporaries said about hum, how they already interpreted what he said and did, and how many different stories circulated about him already in his lifetume. This is closer to an accurate renderng of the historical process of tradition.

This external perspective leads to some provocative statements. "Three crosses high up on Golgotha-no unusual sight at that time!" In a letter written directly after the crucifiction of Jesus we are informed that "for a long time Jerushalaim has not had such a quiet pascha". No, for the majority of the contemporanes of Jesus nothing had changed at all. This provocative stand marks decisive difference between the kind of novel exemplified by Runser's monoperspectical Mirjam and Fussenegger's polyperspectuvical Sie waren Zeitgenossen. Whereas Rinser presents a very clearly shaped personal image of Jesus Chnst, Fussenegger respectfully abstains from presenting a Jesus of her own making. Whereas Runser or her character Murjam tell us everything they know and want to convince us of what is reported so that we accept the information we get, Fussenegger invites her readers to play a much more active role. We, the readers, know that this pascha was the central starting point for Christianty. How then could such a humble beginningone which was not even noticed by many of his contemporaries in Israel, let alone in Rome-lead to such a world wide movement? The author does not give the answer herself but invites us, the readers, to do so.

Two other recently published books employ a similar technique. Whereas Fussenegger mainly concentrates on the ruling class in Israel, Werner Koch's Diesseits von Golgotha (1986) considers the life of the simple people who lived "this side of Golgotha" in the time of Jesus. Gerd Theissen with his book Shadow of the Galilean (1986) is the first biblical scholar who successfully turns to a narrative presentation of hus themes, wnting a kind of novel to present his knowledge about Jesus and his time. Both Koch and Theissen adopt Fussenegger's extemal perspective: Jesus never enters the stage directly and 
we only get to know about him by what his contemporaries tell us. All we actually see is indeed the "shadow" of Jesus, the traces of the man from Galilee. His unique aura is not presented by describing him directly but by describing his unique influence on people.

Thus literary device seems to represent a much more promusing approach than the direct presentation through one single first-person-narration. Nevertheless, the latter device is still much more adequate than the attempt to rewrite some kund of 'histoncal novel' about Jesus in our time in the tradition of Emest Renan's or Francois Maunac's Vie de Jésus or Giovannı Papin's Storia di Cristo. This however is just what the French journalist Gerald Messadié did in his L'homme qui devient Dieu (1988) and his L'incendiaire. Vie de Saul, apôtre (1991) - the first a book about Jesus, the second one about Paul. ${ }^{15}$ These, in France and Germany, hughly successful novels employ traditional techniques: omniscient narrator, direct presentation, psychological interpretation of the protagonists, and so on. They combine these traditonal techniques however with radical theological assertions. According to the first book Jesus did not really die on the cross but survived and his disciples made up the story of his resurrection; according to the second book Paul in fact was not a Jew and for this reason he 'invented' Chnstianity as a world religion very much against the original teaching of Jesus. Neither in their populistic literary form nor in their would-be historical message can these books satisfy the informed reader.

Jesus in dialogue with legendary or mythical figures

One last literary technique still has to be considered. Here Jesus is not being confronted with biblical characters, but with legendary or mythical figures. The most important example here is the novel Ahasver published by the Jewish author Stefan Heym in 1981. With his well known King David Report from 1972, Heym had already written a very clever adaptation of a biblical theme. Now he turned to the legend of the 'wandering Jew', an ant-Jewrsh tradition that can be traced back as far as at least the sixteenth century. According to this legend Ahasver, a Jewish shoemaker who lived in Jerusalem at the times of Jesus, did not allow Jesus to rest in front of his house on his way to Golgotha. For this reason Jesus condemned him to wander restlessly through the world until his second coming. Ahasver has always been one of the most important motifs in world literature: Shelley and Goethe wrote about him as well as Lagerkvist and Strindberg and many more. ${ }^{16}$ Within the Jewish tradition many Jews saw their collective destany prefigured in this fictional character.

Heym's very carefully researched novel is constructed on four different tume levels. The first is some kund of transcendent eternity, where Ahasver and Lucifer are presented as the two fallen angels. But where Lucifer hates 
the world and tries to destroy it, Ahasver tries to make the best of it for humankınd. The second time level leads us back to the time of Jesus, where Ahasver tnes to provoke him to do whatever he can for the improvement of the living conditions on earth instead of accepting life as it is. The third level takes us into the sixteenth century to a contemporary of Martin Luther, the protestant bishop Paul von Eitzen, an histoncal figure, who proclaimed that he had met and talked to Ahasver in person. The last time level confronts us with Heym's own biographical context, the communist society of the DDR in the late seventies, where a historian tries to collect all information about the Ahasver tradition. His very funny correspondence with a colleague in Israel gives an ironic portrait of the scientific academic world. These four time levels are ingemously combined to a highly sophisticated whole.

How does the Jewssh author Heym, who-like Aitmatow-declares humself to be an atheist, portray Jesus? His Jesus, once again the Jewish "Reb Joshua", is first of all an obedient son, who does just what he has to do in the name of hus father. Being permanently provoked by Ahasver: "When everything is sard and done, will you then just once ask yourself the question that has to be asked: What have I changed?" he finally challenges "GodFather" to answer this question. When the latter does not give an answer Jesus tries to revolt against him but in this very moment the tume of the world is fulfilled, the day of the apocalypse has come. Ahasver's question remains without an answer. This novel pretends neither to present historical facts, nor to make a religious profession. Instead it asks fundamental questions about the meaning of life, about man's attitude between revolt and humlity and about the truth and meaning of the Jewish and Christian religion in the context of the possibility of the man-made apocalypse.

A sumular attempt to confront Jesus with legendary figures is made in a novella published in 199I. The young German writer Patnck Roth, who now lives in Los Angeles, invents in his Riverside: Eine Christuslegende the fictuonal character of a Jew with the name of Diastasimos who meets Jesus. What is interestung in this novella is not so much the story as such, but the creative language in which it is presented. Knowing very well that a Jesusnovel in the old tradition can very easily become kitsch, Roth invents a rather old fashioned style of language partly influenced by the language of old Bibletranslations, but virtually a language of its own. In this language and in an unusual dialogical form of presentation Roth manages to write a Jesus-novel that is neither satiric nor ironic, neither historical nor confessional, but in which a certain aura of something unique of this Jesus-no-one like himis realized.

Literary renaissance of Jesus - summary

Looking back at the broad tradition of Jesus-novels in the last twenty years the first point to be made is obvious. Literature has indeed rediscovered Jesus 
as a literary figure. Jesus is still (or shall we say more than ever?) a figure of worldwide interest. The questions of who he was and what he did and how he influenced the history of mankind are sall being asked both within and without the Christan churches. Authors from Russia to Germany, from Canada to France, from Ireland to Portugal, from Spain and Italy to England turn to Jesus for very different reasons and write Jesus-novels with very different forms and techntques. They write about him in historical novels (Messadié), they use biblical characters to give their account of what had happened (Vidal, Hocquengham, Jens, Runser, Roberts, Barnhardt, Aitmatow), they present his very own account of his life and ideas (Barreau, de Rosa, Saramago), they send contemporary figures of our tume back into history to give their own report of what had happened (Vidal, Benitez), they approach Jesus by reporting the witness of a whole range of his contemporaries (Jackman, Fussenegger) or they use legendary or mythical figures to give a portrait of Jesus (Heym, Roth).

Especrally the two technques mentroned last of all are new to the tradition of the Jesus-novel. They demonstrate, how the old tradition of the 'fictionalzing biographies' can be transformed in a way that seems to be in a line with today's literary taste and produce very remarkable works of fiction about Jesus even in the nineties. The aims of such works are clear. Some authors make a personal confession (Jackman, Benitez, Rinser, Fussenegger), others present ironical and satirical revisions of the Jesus-story (Ferruci, Roberts, Vidal, Saramago), introducing pseudo-historical facts (Messadié) or using Jesus as a warning-figure (Aitmatow).

Two general tendencies in the novels described above should be singled out for special attention. First, it is surprising to note that non-Christian and even non-religious authors turn to Jesus in order to present an ethucal message to mankind in times of a threateningly possible man-made apocalypse. Secondly it is no less surprising to realize that most of the literary authors who wnte about Jesus try to go back to the concrete Jewish man Jeshua. From Messadié to Rinser, Fussenegger to Heym, Jackman to TheissenJesus is rediscovered primarily as Jeshua the Jewish rabbi living in the Jewish context of his tumes. In the case of those authors who try to portray hum at the same time as the Chnst of Christian belief, mixing doctrinal christology with fictionalizing biography and trying to give a confession of their personal faith, we find that a literary frontier seems to have been crossed leaving a very unsatisfactory result from the literary point of view.

Let us finally turn to a brief consideration, or rather to some hints concerning the question: can this whole tradition of Jesus-novels be seen as a challenge to the theological interpretations of Jesus? What is it that makes Jesus attractive to those authors who do not believe in hum as the Christ? What is the peculiarity of this so called "no-one like him" (Roth)? And 
what does the explicit turn of these Jesus-novels to Jeshua the Jewish man in his time and context imply? Clearly the Jesus of these novels is neither the Jesus we are confronted with in the New Testament itself nor the Jesus of Christan theological doctrne. The novels enable us to look at the Gospels from a new perspective, to re-read them with sharpened attentiveness. They ask questions about the hustorical rehability of the gospels and of the adequacy of theological interpretations and traditions well worth considering. No christological theory of our time should overlook a detailed answer to these questions and items. The literary, and one should add, the contemporary reception of Jesus in films, works of art or in other media, has to be taken seriously as a source for theological insights. Without assuming to replace 'revelation', these Jesus-novels, written by our contemporaries in a language and in a way of thinkung that is rooted in the present, challenge our traditional theological language and ways of thinking. As far as I know, however, such a truly dialogue-orientated contemporary chnstological study that takes all these aspects into account has not been written yet.

\section{Tübingen/Koblenz}

\section{REFERENCES}

The author usshes to thank Dr. Thomas Riplinger, Tubingen, for assistance wrth his English

${ }^{1}$ See $T$ R. Wright, Theology and Literature (Oxford, I988); David Jasper, The Study of Literature and Religion An Introduction (Basingstoke, 1989, 2nd Ed 1992).

2 Theodore Ziolkowsk1, Fictional Transfiguranons of Jesus (Princeton, 1972).

3 Ibid., p. 6

4 Ibid., p 16

${ }^{5}$ Ibid., p. 17. Zlolkowskı overlooks a couple of important novels of this category, for example Jan Dobraczynski's Listy Nikodema (1950) or Max Brod's Der Metster (1952). For an international bibliography of Jesusnovels see Alice L. Burney, The Literary Lives of Jesus. An Intemational Bibliography of Poetr, Drama, Fiction and Critiasm (New York and London, 1989).

${ }^{6} \mathrm{He}$ distungushes-sometumes not very convinangly-between five different types of transfigurations: the "chrstuan socialıst", the "chnstomaniacs", the "mystac Jesus", the "comrade Jesus" and the "fifth gospel".

${ }^{7} \mathrm{Kar}-J o s e f$ Kuschel, Jerus in der dewtschspra- dhigen Gegenwartsliteratur' 1978 (Munchen, 1987). This study-2 "classic" in the German-speaking world in the field of "hterature and theology" - has unfortunately not been translated into English, although it does not concentrate on German literature alone, but includes English, French and other works of hterature See also Kuschel's anthology of literary texts: Der andere Jesus. Ein Lesebuch modemer literarischer Texte ${ }^{1} 198_{3}$ (Munchen, 1987).

I Ibid, (1987) p. 387

'Recently the German author Phulipp Vandenberg published a novel with the same title: Das finfte Evangelium. Roman (Bergasch Gladbach, 1993) Presented 2s a thriller in the way of Eco's The Name of the Rose this novel does not manage to achieve any distinction.

${ }^{10}$ See' Josef Imbach, Gesù nella Letteratura Contemporanea (Roma, 1983), Femando Castelli, Voltt di Gesù nella Letteratura Modema, 3 vols (Mulano, I987-1991); Georg Langenhorst, Die literarische Wiederentdedeung Jesu in Romanen der acheziger Jahre; Jesus im modemen Roman- 
Schrifisteller auf den Spuren seiner Zettgenossen, in Stimmen der Zett 210 (1992), pp 751-60, 819-30, Kitsch oder Kunst? Romane beschdftigen stch mit der Gestalt Jesu, in Herder Korrespondenz 48 (1994), pp. 315-9

"Gore Vidal, Lue from Golgotha (New York, 1992)

${ }^{12}$ She wrote this book together with Jess Stearn. Among her other novels there are at least two more books which can be classified as 'Jesus-novels' Dear and Clonous Physiaian (1959) and Great Lon of God (1970)

${ }^{13}$ Altmatow in Ruchtplatz Literatur. Tschingis Aitmatow in Loccum, Ed O Schwenke, p. 50, 73 .
${ }^{14}$ See further, Susan Haskuns, Mary Magdalen (London, 1993)

${ }^{13}$ Another important novel on Paul Jan Dobraczynski, Sunety miecz (The Holy Surord) (1949). For the figure of Paul in modern literature see: Georg Langenhorst, Neues und Altes wom "selbstemannten Apostel" Paulus als literansche Figur, in Orientienung 56 (1992), pp 247-so

${ }^{16}$ The most recent 'Ahasver-novel': Jean d'Ormesson, Historre de Juif Errant (Раns, 1990) See: Georg Langenhorst Auf den Spuren Ahasvers. Literansche Anndherungen an den "eungen Juden", in, Orientierung 57 (1993), pp. 207-10. 